\title{
SISTEM INTERAKTIF MEMBACA PERMULAAN BAGI ANAK USIA DINI
}

\author{
Suherman ${ }^{1}$, Mumuy Muhdiah ${ }^{2}$ \\ 1suherman.unsera@gmail.com, ${ }^{2}$ muy_peace@yahoo.com \\ 1,2Universitas Serang Raya, Banten
}

\begin{abstract}
Abstrak
Pendidikan anak usia dini (PAUD) adalah jenjang pendidikan sebelum jenjang pendidikan dasar yang merupakan suatu upaya pembinaan yang ditujukan bagi anak sejak lahir sampai dengan usia enam tahun. Penelitian ini dengan menggunakan metode abjad, bunyi dan gambar. Penelitian ini bertujuan untuk mengetahui pengaruh pembelajaran media interaktif terhadap semangat, dan minat anak dalam membaca permulaan. Penelitian membaca permulaan ini digunakan untuk anak usia 4-5 tahun. Untuk pengujian hasil penelitian berjumlah 20 siswa, dan diambil sampel sebanyak 10 siswa untuk tahun pelajaran 2015/2016. Sebagai pengamat dilakukan oleh 3 guru dan 1 kepala sekolah. Pengumpulan data dalam penelitian ini dilakukan dengan cara observasi, kuesioner, wawancara dan dokumentasi. Penelitian dilakukan di PAUD Pelita Hati Pandeglang. Berdasarkan hasil penelitian, yaitu (1) Terdapat perbedaan ketika menggunakan pembelajaran seperti biasa dengan menggunakan media pembelajaran interktif (2) Kata yang diperkenalkan dibatasi oleh 10 kata, yaitu : Papa, Mama, Bibi, Buku, Baju, Nasi, Mata, Gigi, Kuku, Kaki (3) Pembuatan media interaktif yang dibuat bisa dikembangkan lebih beragam lagi dalam hal animasi, desain, fitur, musik serta pemrograman yang lebih efisien.
\end{abstract}

Kata Kunci : membaca permulaan, anak usia dini, metode abjad, bunyi dan gambar.

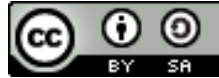

\section{Pendahuluan}

Membaca Permulaan merupakan suatu keterampilan yang sangat unik serta berperan penting bagi perkembangan pengetahuan, dan sebagai alat komunikasi bagi kehidupan manusia. Seseorang akan memperoleh informasi, ilmu pengetahuan serta pengalaman-pengalaman baru dengan cara membaca. Semua yang diperoleh melalui bacaan itu akan memungkinkan orang tersebut mampu mempertinggi daya pikirannya, mempertajam pandangannya, dan memperluas wawasannya. Dengan demikian maka kegiatan membaca merupakan kegiatan yang sangat diperlukan oleh siapapun yang ingin maju dan meningkatkan diri. Oleh sebab itu, peran guru mengajarkan membaca permulaan di sekolah sangat penting.

Menurut hasil wawancara observasi kepada guru PAUD Pelita Hati, hal yang menjadi penyebab rendahnya membaca permulaan anak usia 4-5 tahun Kelompok $A$, diantaranya: media pembelajaran yang masih menggunakan kartu bergambar kurang tepat dan menarik, keterbatasan guru dalam menggunakan metode yang bervariasi, motivasi dan minat anak didik itu sendiri masih sangat rendah.

Dalam membangun media interaktif untuk membaca permulaan bagi anak usia dini dengan menggunakan Metode abjad, bunyi dan gambar ini dimulai dengan mengenalkan huruf-huruf secara alphabetis. Huruf-huruf tersebut dilafalkan anak sesuai dengan bunyinya menurut abjad, mengenalkan huruf vokal dan mengenalkan huruf konsonan, kemudian acak huruf yaitu mencari huruf vokal, mencari huruf konsonan, dan uji coba kemampuan dasar, dan yang terakhir yaitu uji coba membaca permulaan dengan tujuan supaya anak sudah mampu membaca dengan benar atau belum.

Komputer yang digunakan yaitu sebagai alat bantu dan tidak dirancang khusus untuk kegiatan pembelajaran. Dengan pemanfaatan komputer yang disajikan, suatu informasi yang lebih menarik apabila ditampilkan dalam suatu media yang dapat menggabungkan berbagai bentuk informasi. Aplikasi yang dianggap cocok untuk kebutuhan ini adalah aplikasi software multimedia. Multimedia dapat menyajikan informasi yang dibutuhkan oleh para pengguna informasi melalui bentuk gambar, animasi, teks, suara atau video, sehingga mudah dicerna oleh siapa saja. Penggunaan aplikasi ini diharapkan dapat memberikan informasi secara cepat, tepat dan menarik tujuannya agar para pengguna informasi dapat memilih jenis informasi yang dibutuhkan. 
Adapun materi pelajaran yang diberikan kepada subjek penelitian ini adalah tentang membangun media interaktif untuk membaca permulaan melalui perbantunn komputer dan suara beragam. Semua materi tersebut dirancang dalam penyajian yang menarik.

\section{Landasan Teori}

Susana Limanto (2008): Peningkatan Minat Dan Kemampuan Anak Usia Pra Sekolah Untuk Belajar Membaca Dan Menulis Permulaan Menggunakan Komputer Aided Learning. Penelitian ini membahas tentang alat bantu pengajaran yang dibuat dapat mengakomodasi kebutuhan pemakai, anak berusia 4 sampai 5 tahun, maka sebelum alat bantu tersebut dibuat perlu dilakukan analisis dan desain yang tepat. Analisis dilakukan dengan menyebarkan kuisioner kepada 30 orang tua murid yang mempunyai anak berusia antara 4 sampai 5 tahun dan kepada 30 orang guru Taman Kanak-Kanak (TK). Responden diambil dari orang tua murid dan guru TK, karena mereka dianggap sudah memiliki banyak pengalaman mengajar anak belajar membaca dan menulis permulaan [1].

Luh Wini Ayu Wreti Kandayun, Made Sulastri dan Putu Rahayu Ujianti (2015) : Implementasi Metode Bermain Dengan Kartu Suku Kata Untuk Meningkatkan Kemampuan Membaca Permulaan Anak Kelompok B1 TK Kemala Bhayangkari 2 Singaraja. Penelitian ini merupakan penelitian tindakan kelas (PTK) yang secara umum bertujuan meningkatkan dan memperbaiki kualitas proses pembelajaran dikelas yang bermuara pada peningkatan hasil belajar siswa. Penelitian ini dilaksanakan pada satu kelas yang mempunyai masalah pembelajaran. Penelitian ini dilaksanakan pada semester II Tahun Pelajaran 2014/2015 di TK Kemala Bhayangkari 2 Singaraja. Tindakan yang dilakukan adalah Implementasi metode bermain dengan media kartu suku kata untuk meningkatkan kemampuan membaca permulaan anak. Masing-masing siklus terdiri atas empat tahapan, yaitu: perencanaan, pelaksanaan tindakan, observasi dan evaluasi tindakan, dan refleksi [2].

Rustono WS (2011): Pengaruh Metode Pembelajaran Membaca Dan Tingkat Kecerdasan Terhadap Kemampuan Pemahaman Bacaan (Studi Eksperimen Di SDN Dadaha I). Penelitian ini membahas tentang bagaimana untuk mengetahui pengaruh metode belajar kemampuan Intelligence Quotient (IQ) murid dalam membaca. Penelitian ini dilakukan di SDN 1 Dadaha Kota Tasikmalaya dengan 36 murid di kelas pertama di tahun 2009-2010 sebagai sampel yang diambil secara acak. Penelitian ini bertujuan untuk memperoleh data empiris tentang pengaruh metode pembelajaran membaca dan tingkat kecerdasan terhadap kemampuan membaca. Sesuai dengan permasalahan dan tujuan yang hendak dicapai, penelitian ini menggunakan metode eksperimen di mana siswa diajarkan dengan menggunakan dua metode pembelajaran yang berbeda. Pada kelas eksperimen, siswa diajarkan membaca dengan menggunakan metode pembelajaran membaca SAS, sedangkan pada kelas kontrol siswa diajarkan membaca dengan menggunakan metode pembelajaran membaca Kata Global. Selain itu, kedua kelas juga diberikan tes kecerdasan pada akhir pembelajaran dengan tujuan untuk melihat pengaruh dari tes kecerdasan terhadap hasil belajar membaca pada kedua kelas. Rancangan yang digunakan pada penelitian ini adalah Rancangan $2 \times 2$ faktorial [3].

Azizah Nur Fitriana (2005): Strategi Pembelajaran Dalam Proses Membaca Dan Menulis Permulaan. Penelitian ini merupakan penelitian tindakan kelas dengan menggunakan metode deskriptif kualitatif. Dalam penelitian tindakan kelas ini digunakan model Spiral Kemmis dan Mc Taggart (1988) dengan prosedur penelitian yang terdiri atas perencanaan-tindakan observasi/evaluasi-refleksi yang bersifat daur ulang atau siklus. Metode ini juga sesuai dengan karakteristik penelitian yang mengarah pada penelitian kualitatif sebagaimana yang disebutkan oleh Bodgam dn Biklen dalan Amirruddin (1990) bahwa penelitan kualitatif memiliki karakteristik 1) natural setting 2) bersifat deskriptif, 3) lebih mengutamakan proses dari pada hasil 4) analisis data dilakukan secara induktif, dan 5) makna merupakan perhatian utama. Selain itu, pengolahan data pene;itian ini dilakukan dalam bentuk pendeskripsian tanpa menggunakan rumusrumus statistik. Penelitian ini juga bertujuan untuk mengetahui sejauh mana pengaruh metode multisensori dalam meningkatkan kemampuan membaca permulaan pada anak-anak Apakah terjadi peningkatan kemampuan membaca permulaan pada kelompok eksperimen yang diberi perlakuan berupa metode multisensori jika dibandingkan dengan kelompok kontrol yang tidak diberi perlakuan [4].

Betty Dewi Puspasari (2013): Aplikasi Pengenalan Huruf Alfabet Bagi Anak Usia Dini Menggunakan Metode pengolahan Citra Berbasis Data Suara. Penelitian ini merupakan Teknik analisa data disini didasarkan pada metode speech recognition yaitu pembacaan sinyal suara oleh komputer yang direpresentasikan dalam bentuk tampilan grafik sinyal suara dan tampilan suara. Grafik dan suara yang dihasilkan oleh suara dalam library dan suara anak akan dianalisa berdasarkan kemiripan atau similaritas secara audio dan visual dan secara pengolahan citra (image processing). Aplikasi pengenalan huruf 
alfabet ini menampilkan data dalam audio dan visual dalam bentuk histogram dari grafik. Dengan menggunakan tampilan data dalam Audio visual dan gambar grafik, dapat membandingkan pengucapan yang benar dan anak usia dini. Perbandingan dapat dilakukan dengan dua cara. Perbandingan pertama adalah perbandingan audio visual, secara keseluruhan hasil yang diperoleh $73,8 \%$ benar dan $26,2 \%$ tidak benar. Perbandingan yang kedua dengan menggunakan metode Image Processing, hasil keseluruhan yang diperoleh, dengan menggunakan kesamaan itu $74,5 \%$ benar dan $25,5 \%$ tidak benar [5].

\section{Metode}

Dalam melakukan strategi belajar membaca permulaan di PAUD Pelita Hati, metode yang di terapkan menggunakan Metode, bunyi dan gambar. Menurut Akhadiah (dalam Sunarni, 2014: 18-19) Metode abjad dan metode bunyi merupakan metode-metode yang sudah sangat tua. Dalam penerapannya, kedua metode tersebut sering menggunakan kata-kata lepas. Beda antara metode abjad dan metode bunyi terletak pada pengucapan huruf. Pada metode abjad, huruf diucapkan sebagai abjad (/a/, /be/, /ce/, dan seterusnya), sedangkan pada metode bunyi, huruf diucapkan sesuai dengan bunyinya [a], [b], [c], dan seterusnya. Contoh: bo-bo menjadi bobo [6].

Menggunakan metode abjad, bunyi, dan gambar tujuannya supaya anak lebih cepat memahami, dan mengerti dalam materi yang di sampaikan, karena di usia dini anak lebih suka bermain sambil belajar. Untuk membuat anak tertarik dan mau belajar membaca permulaan, penulis memberikan jalan alternative melalui perbantuan komputer. Oleh karena itu, disusun melalui tahapan-tahapan pembelajaran yang disajikan perlevel, supaya proses belajar mengajar lebih efektif dan anak lebih giat lagi dalam pembelajaran membaca permulaan.

Menyajikan pembelajaran membaca permulaan dengan metode abjad ini dimulai dengan mengenalkan huruf-huruf secara alphabetis. Huruf-huruf tersebut dilafalkan anak sesuai dengan bunyinya menurut abjad.

Adapun tahapan dalam penyajian Metode abjad, bunyi dan gambar untuk membaca permulaan anak usia dini PAUD Pelita Hati, melalui perbantuan komputer dalam materi yang akan disampaikan terdiri dari tiga level, yaitu : (1) Mengenalkan huruf abjad dan bunyi A-Z, huruf Vokal : (a, i, u, e, o), dan huruf Konsonan : (b, c, d, f, g, h, j, k, I, m, n, p, q, r, s, t, v, w, x, y, z) (2) Acak huruf, mencari huruf vokal dan mencari huruf konsonan, uji coba kemampuan dasar (3) Uji coba membaca permulaan. berikut :

Diagram Alur Media Pembelajaran Menggunakan Metode Abjad, Bunyi dan Gambar sebagai

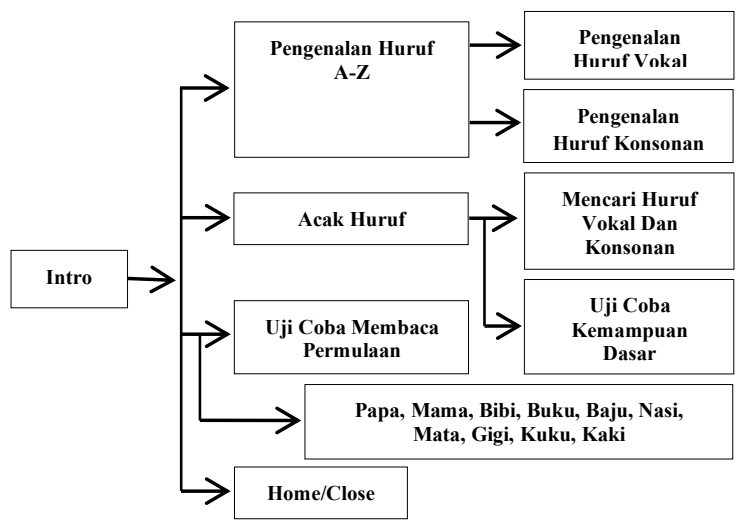

Gambar 1. Diagram Alur Media Pembelajaran Menggunakan Metode Abjad, Bunyi dan Gambar.

Metode pengumpulan data yang digunakan dalam penelitian ini adalah metode observasi dan metode percakapan. Metode observasi adalah suatu cara untuk mencari data dengan melakukan pengamatan pada seluruh anak yang nantinya dapat menimbulkan suatu nilai dan nilai tersebut dapat dibandingkan dengan nilai lain maupun suatu standar. Sedangkan metode percakapan digunakan untuk mencari data tentang perkembangan membaca permulaan anak. Instrumen yang digunakan adalah instrument observasi dan instrumen percakapan dengan tekhnik penilaian penggunaan lima alternatif pilihan jawaban yang digunakan untuk mengukur tingkat kepuasan terhadap hal yang ditanyakan. 


\section{Hasil}

Penelitian ini dilaksanakan di Pendidikan Anak Usia Dini (PAUD) Pelita Hati di Pandeglang Tahun Ajaran 2015/2016 dengan jumlah anak 10 siswa. Kegiatan penelitian ini dilaksanakan selama 3 bulan yaitu dari bulan Nopember 2015 sampai dengan Januari 2016. Data yang dikumpulkan mengenai membaca permulaan anak melalui penerapan metode Abjad, Bunyi dan Gambar.

Setelah observasi selesai dilakukan berikutnya dilakukan desain. Desain yang dilakukan meliputi desain. Pada perangkat lunak yang dibuat, desain model sistem perangkat ajar yang digunakan adalah model tutorial. Model tutorial merupakan cara menyampaikan materi yang dikontrol oleh perancang untuk mempresentasikan bahan-bahan materi ke siswa secara bertahap dan teratur dengan penjelasan. Sedangkan, model dialog yang digunakan adalah model dialog bertingkat, karena sistem ini membagi materi menjadi beberapa tingkat kesulitan, sehingga pengajar atau siswa dapat menentukan tingkat materi yang diinginkannya.

Sistem perangkat ajar dirancang secara khusus untuk anak umur empat sampai lima tahun yang tidak mempunyai masalah keterlambatan belajar. Pertama-tama materi disampaikan dalam bentuk gambar disertai dengan kata-kata sederhana yang sudah dikenal anak dalam kehidupan sehari-hari kemudian dilanjutkan dengan menggunakan gambar dan cerita pendek.

Hasil dari desain kemudian diimplementasikan dengan menggunakan aplikasi Macromedia Director Mx 2004, Adobe Audition dan Adobe Illustrator.

\subsection{Implementasi}

Dari hasil sistem yang telah dibangun diimplementasikan pada anak usia dini di TK Pelita Hati Pandeglang dengan pendampingan para guru pendidik di TK tersebut. Adapun tahapan (level) yang diajarkan oleh sistem ini adalah sebagai berikut:

\section{Level 1}

(1) Mengenalkan huruf abjad dan bunyi A-Z, Pada tahap ini anak diajak untuk mengenali huruf $A$ sampai dengan $Z$ dengan cara mengarahkan pointer mouse ke salah satu huruf kemudian menekannya, ketika huruf itu di tekan maka akan terdengar suara dari huruf tersebut, misalkan "A" dan seterusnya sampai dengan huruf "Z". Pelajaran ini dapat diulangulang sampai anak betul-betul mengetahui huruf, bentuk huruf dan bunyinya.

(2) Mengenalkan huruf Vokal : (a, i, u, e, o),

Pada tahap ini anak diajak untuk mengenali huruf-huruf Vokal dan juga cara bacanya. Implementasinya sama dengan tahap (1) di atas, yaitu mengarahkan pointer mouse ke salah satu huruf kemudian menekannya, ketika huruf itu di tekan maka akan terdengar suara dari huruf tersebut, misalkan "A" dan seterusnya sampai dengan huruf "O".

(3) Mengenal huruf Konsonan : (b, c, d, f, g, h, j, k, I, m, n, p, q, r, s, t, v, w, x, y, z)

Pada tahap ini anak diajak untuk mengenali huruf-huruf Konsonan dan juga cara bacanya. Implementasinya sama dengan tahap (1 dan 2) di atas, yaitu mengarahkan pointer mouse ke salah satu huruf kemudian menekannya, ketika huruf itu di tekan maka akan terdengar suara dari huruf tersebut, misalkan "B" dan seterusnya sampai dengan huruf "Z"

\section{Level 2}

Pada level 2 ini pada dasarnya anak di ajak untuk mengasah kemampuan otak nya untuk mengingat kembali pelajaran yang telah diberikan. Yaitu sebagai berikut :

(1) Mencari huruf Vokal

Pada tahap ini anak diberikan huruf A sampai dengan Z, kemudian anak di tuntut agar dapat mencari huruf Vokal dengan cara mengklik huruf tersebut. Bila anak memilih huruf yang bukan huruf yang dimaksud (huruf Vokal), maka sistem akan menolaknya dengan peringatan suara "OOW"

(2) Mencari huruf Konsonan,

Pada tahap ini anak diberikan huruf A sampai dengan Z, kemudian anak di tuntut agar dapat mencari huruf Konsonan dengan cara mengklik huruf tersebut. Bila anak memilih huruf yang bukan huruf yang dimaksud (huruf Konsonan), maka sistem akan menolaknya dengan peringatan suara "OOW" 
(3) Uji coba kemampuan dasar baca permulaan

Pada tahap ini anak di ajarkan mengenal kata dasar berikut gambarnya, kata tersebut yang mudah diingat oleh anak yang terdiri dari 2 (dua) suku kata, yaitu Papa, Mama, Bibi, Buku, Baju, Nasi, Mata, Gigi, Kuku dan Kaki. Pada pelajaran ini sistem akan menampilkan per suku kata dan cara bacanya, seperti PAPA menjadi PA-PA, setelah itu anak juga diajarkan bagaimana cara baca ketika disambungkan, menjadi PAPA

\section{Level 3}

(1) Uji coba membaca permulaan

Pada tahap ini sistem akan menguji kemampuan anak hasil dari pelajaran uji coba kemampuan dasar baca permulaan. Sistem akan menampilkan gambar dan 4 (empat) kotak kosong di bawahnya serta abjad dari A sampai dengan Z. Anak kemudian di uji untuk memilih abjad-abjad yang tersedia yang sesuai dengan gambar sehingga membentuk sebuah kata dan bunyi dari kata tersebut melalui tombol baca. Contoh gambar 2 di bawah ini menunjukkan salah satunya.

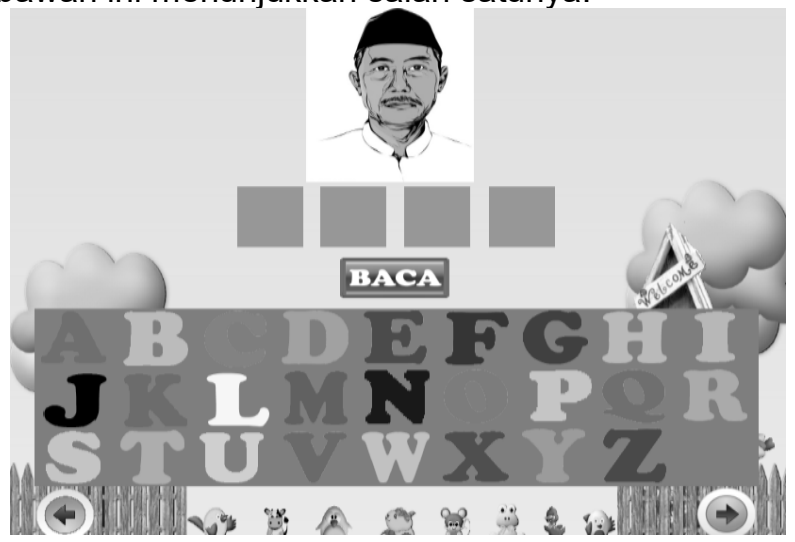

Gambar 2. Uji Coba Membaca Permulaan

\subsection{Uji Coba Pemakai}

Kegunaan instrumen penelitian adalah untuk memperoleh data yang diperlukan ketika peneliti sudah menginjak pada langkah pengumpulan informasi di lapangan. Ada empat media yang dapat digunakan untuk mengumpulkan data dalam proses penelitian yaitu kuesioner, observasi, wawancara, dan dokumentasi. Keempat media tersebut penggunaannya dapat dipilih satu macam, atau gabungan antara dua media tersebut, tergantung macam data yang diinginkan peneliti.

Data pengamatan membaca permulaan sebelum dan sesudah implementasi. Adapun hasil pengamatan sebelum dan sesudah implementasi sebagai berikut :

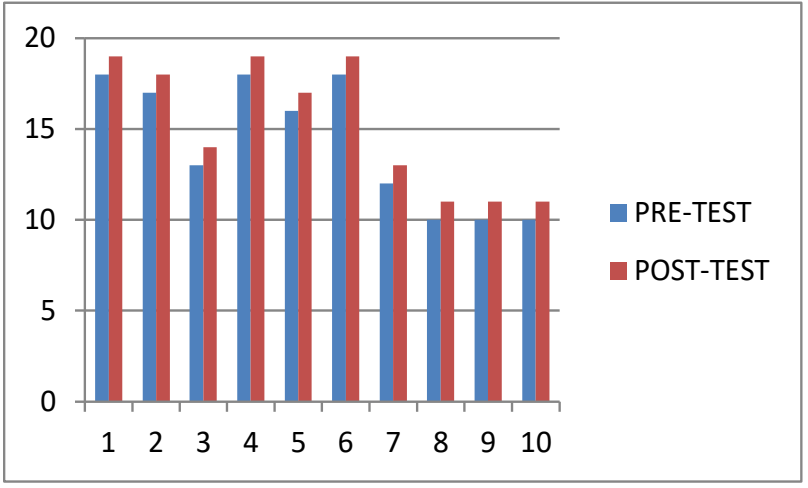

Gambar 3. Grafik Perbedaan Hasil Pre-Test dan Post-Test. 


\section{Kesimpulan dan Saran}

\subsection{Kesimpulan}

Berdasarkan hasil pembahasan dan implementasi yang telah dipaparkan, maka penelitian ini dapat disimpulkan sebagai berikut:

1. Media Interaktif untuk membaca permulaan ini sangat membantu guru dalam kegiatan belajar mengajar PAUD Pelita Hati di Pandeglang.

2. Dengan desainnya yang menarik karena menggunakan perpaduan gambar, animasi dan suara sehingga memudahkan untuk mengajak peserta didik dalam belajar membaca permulaan.

3. Media pembelajaran ini bersifat interaktif dimana pemakai atau user tidak cepat jenuh dan juga dapat menjadi media pembelajaran yang menyenangkan sehingga penguasaan materi dapat dilakukan dengan lebih cepat, karena anak di usia dini lebih menyukai bermain sambil belajar.

\subsection{Saran}

yaitu:

Saran untuk pengembangan sistem pembelajaran membaca permulaan agar lebih baik

1. Dipublish versi online. Hal ini dimaksudkan agar media interaktif membaca permulaan ini bisa semakin dikenal secara luas dan untuk membantu pengajar lainnya.

2. Pembuatan media interaktif membaca permulaan yang dibuat agar dapat digunakan sebagai bahan pembelajaran, terutama dalam membaca permulaan. Karena menggunakan desain yang menarik untuk mengajak anak dalam membaca permulaan.

3. Pembuatan media interaktif pembelajaran membaca permulaan yang dibuat agar dapat dikembangkan lebih beragam lagi dalam hal animasi, desain, fitur, musik serta pemrograman yang lebih efisien. Agar anak usia dini lebih berkembang lagi dalam keinginan membaca permulaan.

\section{Daftar Pustaka}

[1] Limanto, Susana. 2008. "Peningkatan Minat Dan Kemampuan Anak Usia Pra Sekolah Untuk Belajar Membaca Dan Menulis Permulaan Menggunakan Komputer Aided Learning". European Journal Manajemen Informatika. Vol. 9. No. (2). 114-120.

[2] Kandayun, L. W. A. W. Sulastri, Made. dan Ujianti. P. R. 2015. "Implementasi Metode Bermain Dengan Kartu Suku Kata Untuk Meningkatkan Kemampuan Membaca Permulaan Anak Kelompok B1 TK Kemala Bhayangkari 2 Singaraja". European Journal PG PAUD Universitas Pendidikan Ganesha. Vol. 3. No. (1).

[3] WS, Rustono. 2011. "Pengaruh Metode Pembelajaran Membaca Dan Tingkat Kecerdasan Terhadap Kemampuan Pemahaman Bacaan (Studi Eksperimen Di SDN Dadaha I)". European Journal saung guru. Vol. 1. No. (2).

[4] Fitriana, Azizah. N. 2005. "Strategi Pembelajaran Dalam Proses Membaca Dan Menulis Permulaan". European Journal Pendidikan Dasar. Vol. 6. No. (2). 61-118.

[5] Puspasari, Betty. D. 2013. "Aplikasi Pengenalan Huruf Alfabet Bagi Anak Usia Dini Menggunakan Metode pengolahan Citra Berbasis Data Suara”. European Journal ELTEK. Vol. 11. No. (1). 16934024.

[6] Sunarni. 2014. "Peningkatan Keterampilan Membaca Permulaan Melalui Media Animasi Pada Anak Kelompok B1TK KKLKMD Sedyo Rukun, Bambanglipuro Bantul". 